\title{
The use of stem cells in ischemic heart disease treatment
}

\author{
Radoslaw Litwinowicz, Bogusław Kapelak, Jerzy Sadowski, Anna Kędziora, Krzysztof Bartus \\ Department of Cardiovascular Surgery and Transplantology, Jagiellonian University Medical College, \\ John Paul II Hospital, Krakow, Poland
}

Kardiochirurgia i Torakochirurgia Polska 2018; 15 (3): 196-199

\begin{abstract}
Ischemic heart disease is a major cause of death and disabilities worldwide. Unfortunately, not all patients are suitable for direct revascularization. Cell-based therapies may be alternative options because of their potential to promote neovascularisation and endothelial repair, improving myocardial perfusion. The success of cell-based therapies depends on the type of implanted stem cells, delivery method and underlying disease. Several different cell populations including bone marrowderived mononuclear cells (MNCs), mesenchymal stromal cells (MSCs), CD34+, CD133+, endothelial progenitor cells, adiposederived mesenchymal stromal cells (ASCs) and stem cells from placenta and umbilical cord have been investigated. Presently, no consensus exists about the best cell type for clinical regenerative therapy. Because the system of coronary arteries in the ischemic area is poor and most of the coronary artery is significantly narrowed or closed, direct implantation of stem cells in the ischemic area of the heart muscle appears an attractive method.
\end{abstract}

Key words: ischemic heart disease, stem cells, regenerative medicine.

\section{Introduction}

In the U.S. alone 28.1 million people are living with cardiovascular disease, and this number increases every year [1]. Coronary artery disease (CAD) is a major cause of death and disability in developed countries, including in the young adult population [2]. The gold standard for treatment patients with ischemic heart disease is percutaneous coronary intervention $(\mathrm{PCI})$ or coronary artery bypass grafting (CABG) [3-5]. Nevertheless, an increasing number of patients with advanced coronary artery disease become suboptimal candidates for further revascularization, and continue to have symptoms despite the best medical management [6].

Regenerative therapies using stem cells for the repair of heart tissue have been widely used in preclinical and

\section{Streszczenie}

Choroba niedokrwienna serca jest główną przyczyną zgonu i niepełnosprawności na świecie. Nie wszyscy pacjenci mogą jednak być zakwalifikowani do bezpośrednich metod rewaskularyzacji. Alternatywą są terapie oparte na wykorzystaniu komórek macierzystych ze względu na ich potencjał do odbudowy łożyska naczyniowego oraz poprawy perfuzji mięśnia sercowego. Sukces terapii z użyciem komórek macierzystych zależy od rodzaju wszczepionych komórek macierzystych, metody podawania oraz choroby podstawowej. Przebadano kilka różnych populacji komórek, np. jednojądrzaste komórki szpiku kostnego (MNC), mezenchymalne komórki zrębowe (MSC), CD34+, CD133+, śródbłonkowe komórki progenitorowe, mezenchymalne komórki zrębowe pochodzące z tkanki tłuszczowej (ASC) i komórki macierzyste z łożyska, pępowiny oraz serce. Obecnie nie ma konsensusu dotyczącego wyboru optymalnego typu komórek w klinicznej terapii regeneracyjnej mięśnia sercowego. Ponieważ układ tętnic wieńcowych w obszarze niedokrwienia jest słaby, a większość tętnic wieńcowych jest znacznie zwężona lub zamknięta, bezpośrednia implantacja komórek macierzystych w obszarze niedokrwienia mięśnia sercowego wydaje się atrakcyjną metodą.

Słowa kluczowe: choroba niedokrwienna serca, komórki macierzyste, medycyna regeneracyjna.

clinical studies during the past 16 years [7]. Induction of angiogenesis to create de novo collateral vessels within an area of compromised blood flow has been in development since the mid-1980s, soon after the first in vivo reports on the angiogenic effect of recombinant fibroblast growth factor (FGF) [8].

There are several factors that significantly affect the effectiveness of stem cell therapy. Optimal delivery technique is crucial for the precise delivery of stem cells to a specific area of the myocardium, settlement and differentiation. Among the different approaches, direct implantation of cells into heart tissue still attracts the most clinical attention. In this review, we will focus on the intramyocardial delivery of stem cells in treatment of ischemic heart disease.

Address for correspondence: Radoslaw Litwinowicz MD, PhD, Department of Cardiovascular Surgery and Transplantology, Jagiellonian University, John Paul II Hospital, 80 Pradnicka St, 31-202 Krakow, Poland, phone: +48 126143203 , fax: +48 126142525 , e-mail: radek.litwinowicz@gmail.com

Received: 10.06.2018, accepted: 12.06.2018. 


\section{Delivery methods}

The first documented attempt at internal local drug delivery was made by Folkman et al. in 1964 [9]. These investigators attempted to treat surgically induced heart block in dogs through intramyocardial (IMC) release of digitoxin, isoproterenol, tyrosine, thyroid I125, and ethylenediaminetetraacetic acid embedded in a silicone rubber cylindrical capsule $(5 \mathrm{~mm} \times 15 \mathrm{~mm})$ surgically implanted in the myocardial wall near the apex.

A range of technologies have been used to deploy the intramyocardial delivery route, from direct syringe injection to the left ventricle under visual control to minimally invasive delivery using guided percutaneous transendocardial injection to the ischemic area of the left ventricle guided by the NOGA system.

It was found that direct injection into the myocardium immediately after the LAD occlusion provided the largest stem cell retention in the injured myocardium (14 $\pm 4 \%$ of the total injected cells) [10]. Direct surgical myocardial injection can be performed in hypokinetic myocardial areas not suitable for coronary artery bypass grafting (CABG) [11].

Many investigators have explored intracoronary (IC) delivery of therapeutic agents. While this approach preferentially targets myocardial tissue, it usually does not provide significant drug retention in heart muscle.

Penicka et al. [12] demonstrated that approximately 5\% and $1 \%$ of the stem cells remain in the human myocardium $2 \mathrm{~h}$ and $18 \mathrm{~h}$ post-intracoronary application, respectively, while the vast majority of the cells can be found in the spleen, liver, lung, lymph nodes and BM already a couple of hours after transplantation.

Intramyocardial cellular delivery cell therapy provided a benefit in increasing 6-min walk distance $(95 \% \mathrm{Cl}$ : 21.09-142.62 m, $p=0.008)$, improving the Minnesota Living with Heart Failure (MLHF) score ( $95 \% \mathrm{Cl}:-25.21$ to -3.55 , $p=0.009$ ), and lowering the incidence of NYHA functional class deterioration ( $95 \% \mathrm{Cl}: 0.05-0.76, p=0.02$ ). Meanwhile, cell therapy did not significantly increase the incidence of acute heart failure during the cell injection procedure (RR $\left.=1.68,95 \% \mathrm{Cl}: 0.43-6.63, p=0.46 ; P^{2}=0 \%\right)$ or the risk of ventricular tachycardia during follow-up $(\mathrm{RR}=1.56,95 \% \mathrm{Cl}$ : $0.73-3.32, p=0.25 ; P^{2}=0 \%$ ) [13].

Intramyocardial delivery has been implemented via minimally invasive transcutaneous left heart catheterization for transendocardial injection [14] and direct transepicardial injections under direct visualization during sternotomy [15] or left small thoracotomy [16]. Minimally invasive access to the heart muscle is a safe procedure, widely used in cardiac surgery [17]. However, without the use of extracorporeal circulation, it allows only for safe access to the anterior and anterolateral wall of the heart, which may be a limitation of this approach. Full sternotomy meanwhile is associated with the risk of perioperative complications such as bleeding, infections, abnormal sternal healing or respiratory complications $[18,19]$.

Recently published research on animals revealed that intracoronary stem cell delivery decreased absolute myo- cardial blood flow, with a consequent increase in myocardial expression of the oxidative stress marker matrix metalloproteinase-2 and reduced CXCR4 receptor expression with a lower level of myocardial homing and angiogenic factor release as compared to intramyocardial cell delivery [20].

It should be emphasized that patient safety must always be taken into account in the planning of clinical trials. This is especially true given the adverse events reported in the Athena trials [21]. Eighteen of 31 (58.1\%) patients were reported to have at least one serious adverse event during the trial (ADSC 9/17 (52.9\%), placebo 9/14 (64.3\%)). The reasons for such high adverse event rates in the Athena trials are unclear but could be dependent on cell delivery techniques used.

The limitations of intramyocardial delivery include the relatively small volume of drug delivery vehicle, the potential danger of disrupting myocardium, and the iatrogenic damage to coronary vessels or His-Purkinje fibers.

\section{Types of stem cells}

Many types of stem cells are used in scientific research, since the first-in-man application in 2001 and several promising clinical pilot trials [22]. Cell-based therapy promotes tissue regeneration through direct tissue transdifferentiation, paracrine signaling and promotion of neoangiogenesis. Mechanisms responsible for neoangiogenesis involve release of paracrine factors such as vascular endothelial growth factor (VEGF), basic fibroblast growth factor (bFGF), angiopoietin-1 and many others.

Bone marrow-derived mononuclear cells (BM-MNCs) represent a heterogeneous population: hematopoietic stem cells, mesenchymal stem cells (MSCs) and endothelial progenitor cells (EPCS). It is generally accepted that MSCS can express CD44, CD29, CD73, CD90 and CD105, as well as CD106, CD166, and ICAM-1, but not the hematopoietic markers CD45, CD34, CD14, CD79a, CD11b and HLA-DR [23].

Many murine, rat, and swine studies have demonstrated that IMC injections of bone mesenchymal stem cells (BMSCs) into the ischemic and infarcted myocardium induce angiogenesis and myocardial blood perfusion, and improve cardiac function [24, 25].

In the COMPARE CPM-RMI trial, wherein bone marrowderived mononuclear cells (MNCs) and CD133+ stem cells were implanted, increased left ventricular ejection fraction by $9 \%$ (95\% confidence intervals $(\mathrm{Cl})$ : $2.14-15.78 \%$, $p=0.01)$ and improved decreased systolic wall thickening by -3.7 ( $95 \% \mathrm{Cl}:-7.07$ to $-0.42, p=0.03)$ were found in both cell type groups [26]. Patients from all study groups received the injections at the end of the cardiopulmonary bypass and cold blood cardioplegic arrest, and just prior to removal of the aortic cross clamp.

In patients with left ventricle dysfunction, intramyocardial injection of autologous bone marrow mononuclear cells improve regional wall thickening ( $6.6 \pm 6.3 \%$ vs. 11.7 $\pm 7.0 \%$ at 3 months, $p<0.01)$ and perfusion score $(3.5 \pm 0.7$ vs. $3.0 \pm 0.9$ at 3 months, $p=0.02$ ), with a trend toward an improved fluorine-18 fluorodeoxyglucose score ( $2.9 \pm 0.9 \mathrm{vs}$. $2.6 \pm 1.0$ at 3 months, $p=0.06$ ) [27]. 
Also in the long-term follow-up period, clinical status improvement, no new regional wall motion abnormalities and increase of global ejection fraction were observed $[28,29]$.

In conclusion, many clinical trials have demonstrated safety and efficiency of intramyocardial stem cell injections into patients with acute and chronic myocardial infarction, as well as improvement in myocardial perfusion and function [28, 30, 31].

Adipose tissue is one of the most highly vascularized tissues in the body. Adipose tissue-derived stem cells (ADSCS) are a cell population with characteristics that are very similar, but not identical, to those of BMSCs [32, 33].

In animal studies, intramyocardially injected adiposederived stromal cells have demonstrated increased LVEF, wall thickness, and reduction of infarct size in rats [34].

Results from a randomized placebo-controlled study (MyStromalCell Trial) revealed that bicycle exercise tolerance increased significantly by the time of $22 \mathrm{~s}(95 \%$ Cl: -164 to 208 s, $p=0.034), 4$ watts ( $95 \% \mathrm{Cl}:-33$ to 41 , $p=0.048$ ), and 0.2 METs ( $95 \% \mathrm{Cl}:-1.4$ to $1.8, p=0.048$ ) in the adipose-derived stromal cell group while there was a non-significant increase in the placebo group by time of $9 \mathrm{~s}(95 \% \mathrm{Cl}:-203$ to $221 \mathrm{~s}, p=0.053), 7$ watts $(95 \% \mathrm{Cl}:-40$ to $54, p=0.41)$, and $0.1 \mathrm{METs}(95 \% \mathrm{Cl}:-1.7$ to $1.9, p=0.757)$ at 6 months follow-up [35].

The Athena trials used an intramyocardial injection of adipose-derived stromal vascular fraction (SVF) cells in patients with ischemic heart failure and showed that maximum oxygen consumption on exercise treadmill testing was increased in the therapy group but not significantly different from the placebo group [21]. Used SVF cell populations are however heterogeneous, compromising approximately $2 \%$ ASCs [36].

Schenke-Layland et al. reported that compared with the control group, the ADSCs-treated group showed less dilated left ventricular end-diastolic dimension, and significantly improved ejection fraction and cardiac output after MI [37].

Currently, several studies using adipose derived stem cells are in progress. A multicentre, double-blind, placebocontrolled phase II study is designed to demonstrate safety and the regenerative efficacy of direct intramyocardial injections of allogeneic adipose-derived stromal cells in patients with chronic ischemic heart failure [38].

Konstanty-Kalandyk et al. reported the safety and feasibility of delivery of fresh ADSCs intramyocardially, using a medical laser, to patients with chronic ischemic heart disease who did not qualify for standard methods of treatment (percutaneous coronary intervention, coronary artery bypass grafting) [16].

\section{Conclusions}

Intramyocardial delivery of stem cells is more complicated than intracoronary administration, but it is safe and may provide better therapeutic outcomes. Further studies should be designed to define the optimal cell type to treat ischemic heart disease, including combination cell therapy.
Many authors emphasize the importance of proper selection of patients for clinical study using stem cells. Probably some of the patients treated with stem cells respond poorly or not at all to the given stem cells. It may be related to the patient's age, accompanying diseases, medications or individual predispositions of the patients.

\section{Disclosure}

The authors report no conflict of interest.

\section{References}

1. Fihn SD, Blankenship JC, Alexander KP, Bittl JA, Byrne JG, Fletcher BJ, Fonarow GC, Lange RA, Levine GN, Maddox TM. 2014 ACC/AHA/AATS/PCNA/SCAI/ STS focused update of the guideline for the diagnosis and management of patients with stable ischemic heart disease: a report of the American College of Cardiology/American Heart Association Task Force on Practice Guidelines, and the American Association for Thoracic Surgery, Preventive Cardiovascular Nurses Association, Society for Cardiovascular Angiography and Interventions, and Society of Thoracic Surgeons. J Am Coll Cardiol 2014; 64: 1929-1949.

2. Piątek J, Kędziora A, Konstanty-Kalandyk J, Kiełbasa G, Olszewska M, Wierzbicki K, Milaniak I, Song B, Kapelak B, Darocha T. Coronary artery disease in young adults: who needs surgical revascularization? A retrospective cohort study. In: The Heart Surgery Forum 2016.

3. Head SJ, Davierwala PM, Serruys PW, Redwood SR, Colombo A, Mack MJ, Morice MC, Holmes DR Jr, Feldman TE, Ståhle E. Coronary artery bypass grafting vs. percutaneous coronary intervention for patients with three-vessel disease: final five-year follow-up of the SYNTAX trial. Eur Heart J 2014; 35: 2821-2830.

4. Piątek J, Konstanty-Kalandyk J, Kędziora A, Hyochan BS, Wierzbicki K, Darocha T, Milaniak I, Kapelak B. Total arterial myocardial revascularization in patients over 70 years old-a new trend in coronary surgery in elderly. Przegl Lek 2016; 73: 813-815.

5. Konstanty-Kalandyk J, Piatek J, Rudzinski P, Wrobel K, Bartus K, Sadowski J. Clinical outcome of arterial myocardial revascularization using bilateral internal thoracic arteries in diabetic patients: a single centre experience. Interact Cardiovasc Thorac Surg 2012; 15: 979-983.

6. De Lemos J, Omland T. Chronic Coronary Artery Disease: a Companion to Braunwald's Heart Disease. E-book. Elsevier Health Sciences 2017.

7. Fisher SA, Brunskill SJ, Doree C, Mathur A, Taggart DP, Martin-Rendon E. Stem cell therapy for chronic ischaemic heart disease and congestive heart failure. Cochrane Database Syst Rev 2014; 4: CD007888.

8. Franco WP, Bracey AW, Franco KL, Hufnagel CA, Glogar DH, Kloner RA. Fibroblastic growth factor and infarct size. Ann Intern Med 1980; 93: 637-638.

9. Folkman J, Long DM. The use of silicone rubber as a carrier for prolonged drug therapy. J Surg Res 1964; 4: 139-42.

10. Elhami E, Dietz B, Xiang B, Deng J, Wang F, Chi C, Goertzen AL, Mzengeza S, Freed D, Arora RC. Assessment of three techniques for delivering stem cells to the heart using PET and MR imaging. EJNMMI Res 2013; 3: 72.

11. Pavo N, Charwat S, Nyolczas N, Jakab A, Murlasits Z, Bergler-Klein J, Nikfardjam M, Benedek I, Benedek T, Pavo IJ. Cell therapy for human ischemic heart diseases: critical review and summary of the clinical experiences. J Mol Cell Cardiol 2014; 75: 12-24.

12. Penicka M, Widimsky P, Kobylka P, Kozak T, Lang O. Images in cardiovascular medicine. Early tissue distribution of bone marrow mononuclear cells after transcoronary transplantation in a patient with acute myocardial infarction. Circulation 2005; 112: e63-e65.

13. Cheng K, Wu F, Cao F. Intramyocardial autologous cell engraftment in patients with ischaemic heart failure: a meta-analysis of randomised controlled trials. Heart Lung Circulation 2013; 22: 887-894.

14. Tse HF, Kwong YL, Chan JK, Lo G, Ho CL, Lau CP. Angiogenesis in ischaemic myocardium by intramyocardial autologous bone marrow mononuclear cell implantation. Lancet 2003; 361: 47-49.

15. Hamano K, Nishida M, Hirata K, Mikamo A, Li TS, Harada M, Miura T, Matsuzaki M, Esato K. Local implantation of autologous bone marrow cells for therapeutic angiogenesis in patients with ischemic heart disease. Japan Circulation J 2001; 65: 845-847. 
16. Konstanty-Kalandyk J, Piątek J, Chrapusta A, Song BH, Urbańczyk-Zawadzka M, Ślósarczyk B, Majka M, Kędziora A, Bartuś K, Podolec P. Use of adipose-derived stromal cells in the treatment of chronic ischaemic heart disease: safety and feasibility study. Kardiol Pol (Pol Heart J) 2018; 76: 911-913.

17. Wróbel K, Song BH, Darocha T, Wróżek M, Kapelak B. Minimally invasive coronary artery bypass as a safe method of surgical revascularization. The step towards hybrid procedures. Adv Interv Cardiol 2017; 13: 320-325.

18. Litwinowicz R, Bartus K, Drwila R, Kapelak B, Konstanty-Kalandyk J, Sobczynski R, Wierzbicki K, Bartuś M, Chrapusta A, Timek T. In-hospital mortality in cardiac surgery patients after readmission to the intensive care unit: a single-center experience with 10,992 patients. J Cardiothorac Vasc Anesth 2015; 29: 570-575.

19. Litwinowicz R, Bryndza M, Chrapusta A, Kobielska E, Kapelak B, Grudzien G. Hyperbaric oxygen therapy as additional treatment in deep sternal wound infections - a single center's experience. Kardiochir Torakochirur Pol 2016; 13: 198-202.

20. Zlabinger K, Lukovic D, Hemetsberger R, Gugerell A, Winkler J, Mandic L, Traxler D, Spannbauer A, Wolbank S, Zanoni G. Matrix metalloproteinase-2 impairs homing of intracoronary delivered mesenchymal stem cells in a porcine reperfused myocardial infarction: comparison with intramyocardial cell delivery. Front Bioeng Biotechnol 2018; 6: 35.

21. Henry TD, Pepine CJ, Lambert CR, Traverse JH, Schatz R, Costa M, Povsic TJ, David Anderson R, Willerson JT, Kesten S. The Athena trials: autologous adipose-derived regenerative cells for refractory chronic myocardial ischemia with left ventricular dysfunction. Catheter Cardiovasc Interv 2017; 89: 169-177.

22. Stamm C, Westphal B, Kleine HD, Petzsch $M$, Kittner C, Klinge H, Schümichen C, Nienaber CA, Freund M, Steinhoff G. Autologous bone-marrow stemcell transplantation for myocardial regeneration. Lancet 2003; 361: 45-46.

23. Yu H, Lu K, Zhu J, Wang JA. Stem cell therapy for ischemic heart diseases. Br Med Bull 2017; 12: 135-154.

24. Fuchs S, Baffour R, Zhou YF, Shou M, Pierre A, Tio FO, Weissman NJ, Leon MB, Epstein SE, Kornowski R. Transendocardial delivery of autologous bone marrow enhances collateral perfusion and regional function in pigs with chronic experimental myocardial ischemia. J Am Coll Cardiol 2001; 37: 1726-1732.

25. Chacko SM, Khan M, Kuppusamy ML, Pandian RP, Varadharaj S, Selvendiran K, Bratasz A, Rivera BK, Kuppusamy P. Myocardial oxygenation and functional recovery in infarct rat hearts transplanted with mesenchymal stem cells. Am J Physiol Heart Circ Physiol 2009; 296: H1263-H1273.

26. Naseri MH, Madani H, Ahmadi ST, Moshkani MF, Kazemi DS, Hosseinnejad H, Hosseini S, Hekmat S, Hossein ZA, Dehghani M. COMPARE CPM-RMI Trial. Intramyocardial transplantation of autologous bone marrow-derived CD133+ cells and MNCs during CABG in patients with recent MI: a phase II/ III, multicenter, placebo-controlled, randomized, double-blind clinical trial. Cell J 2018; 20: 267-277.

27. Beeres SL, Bax JJ, Dibbets-Schneider P, Stokkel MP, Fibbe WE, van der Wall EE, Schalij MJ, Atsma DE. Intramyocardial injection of autologous bone marrow mononuclear cells in patients with chronic myocardial infarction and severe left ventricular dysfunction. Am J Cardiol 2007; 100: 1094-1098.

28. Rodrigo SF, van Ramshorst J, Hoogslag GE, Boden H, Velders MA, Cannegieter SC, Roelofs H, Al Younis I, Dibbets-Schneider P, Fibbe WE. Intramyocardial injection of autologous bone marrow-derived ex vivo expanded mesenchymal stem cells in acute myocardial infarction patients is feasible and safe up to 5 years of follow-up. J Cardiovasc Transl Res 2013; 6: 816-825.

29. Konstanty-Kalandyk J, Piątek J, Kędziora A, Miszalski-Jamka T, Kapelak B, Bartuś K, Darocha T, Drwiła R, Sadowski J. Long-term follow-up after holmium: YAG laser revascularization combined with autologous bone marrow derived stem cells implantation. Przegl Lek 2017; 74: 91-95.

30. Khan AR, Farid TA, Pathan A, Tripathi A, Ghafghazi S, Wysoczynski M, Bolli R. Impact of cell therapy on myocardial perfusion and cardiovascular outcomes in patients with angina refractory to medical therapy: a system atic review and meta-analysis. Circ Res 2016; 118: 984-993.

31. Konstanty-Kalandyk J, Piatek J, Miszalski-Jamka T, Rudzinski P, Walter Z, Bartus K, Urbanczyk-Zawadzka M, Sadowski J. The combined use of transmyocardial laser revascularisation and intramyocardial injection of bonemarrow derived stem cells in patients with end-stage coronary artery disease: one year follow-up. Kardiol Pol 2013; 71: 485-492.

32. Rodriguez AM, Elabd C, Amri EZ, Ailhaud G, Dani C. The human adipose tissue is a source of multipotent stem cells. Biochimie 2005; 87: 125-128.

33. De Ugarte DA, Alfonso Z, Zuk PA, Elbarbary A, Zhu M, Ashjian P, Benhaim P, Hedrick $M H$, Fraser JK. Differential expression of stem cell mobilizationassociated molecules on multi-lineage cells from adipose tissue and bone marrow. Immunol Lett 2003; 89: 267-270.

34. Wang L, Deng J, Tian W, Xiang B, Yang T, Li G, Wang J, Gruwel M, Kashour T, Rendell J, Glogowski M, Tomanek B, Freed D, Deslauriers R, Arora RC, Tian G. Adipose-derived stem cells are an effective cell candidate for treatment of heart failure: an MR imaging study of rat hearts. Am J Physiol Heart Circ Physiol 2009; 297: H1020-H1031.

35. Qayyum AA, Mathiasen AB, Mygind ND, Kuhl JT, Jorgensen E, Helqvist S, Elberg JJ, Kofoed KF, Vejlstrup NG, Fischer-Nielsen A, Haack-Sorensen M, Ekblond A, Kastrup J. Adipose-derived stromal cells for treatment of patients with chronic ischemic heart disease (MyStromalCell Trial): a randomized placebo-controlled study. Stem Cells Int 2017; 2017: 5237063.

36. Bai X, Alt E. Myocardial regeneration potential of adipose tissue-derived stem cells. Biochem Biophys Res Commun 2010; 401: 321-326.

37. Schenke-Layland K, Strem BM, Jordan MC, Deemedio MT, Hedrick MH, Roos KP, Fraser JK, Maclellan WR. Adipose tissue-derived cells improve cardiac function following myocardial infarction. J Surg Res 2009; 153: 217-223.

38. Kastrup J, Schou M, Gustafsson I, Nielsen OW, Mogelvang R, Kofoed KF, Kragelund C, Hove JD, Fabricius-Bjerre A, Heitman M, Haack-Sorensen M, Lund LD, Johansen EM, Qayyum AA. Rationale and design of the first double-blind, placebo-controlled trial with allogeneic adipose tissue-derived stromal cell therapy in patients with ischemic heart failure: a phase II Danish Multicentre Study. Stem Cells Int 2017; 2017: 8506370. 